\title{
User Guide
}

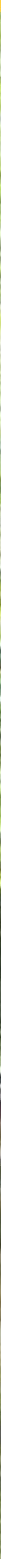

\section{Forest carbon database}

A Web-based carbon stock data repository and exchange system

Sofyan Kurnianto and Daniel Murdiyarso

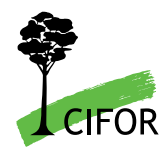

Australian Government

the David

Lucile Packard

约

NORWEGIAN MINISTRY OF THE ENVIRONMENT
NORWEGIAN MINISTRY OF FOREIGN AFFAIRS 

USER GUIDE

\section{Forest carbon database}

A Web-based carbon stock data repository and exchange system

Sofyan Kurnianto

Daniel Murdiyarso 
(C) 2010 Center for International Forestry Research

All rights reserved.

Printed in Indonesia

Kurnianto, S. and Murdiyarso, D. 2010 Forest carbon database: a Web-based carbon stock data repository and exchange system. CIFOR, Bogor, Indonesia

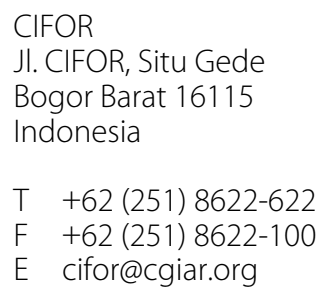

www.cifor.cgiar.org

\section{Center for International Forestry Research (CIFOR)}

CIFOR advances human wellbeing, environmental conservation and equity by conducting research to inform policies and practices that affect forests in developing countries. CIFOR is one of 15 centres within the Consultative Group on International Agricultural Research (CGIAR). CIFOR's headquarters are in Bogor, Indonesia. It also has offices in Asia, Africa and South America. 


\section{Contents}

1. Introduction $\quad 2$

2. Getting started $\quad 3$

2.1 Registration 3

$\begin{array}{ll}2.2 & \text { Logging on to the forest carbon database }\end{array}$

$\begin{array}{ll}\text { 3. Recognising the features of the forest carbon database } & 7\end{array}$

$\begin{array}{ll}3.1 & \text { Adding a new site }\end{array}$

3.2 Uploading raw data 11

$\begin{array}{ll}3.3 & \text { Viewing, editing and duplicating your sites }\end{array}$

\begin{tabular}{ll}
3.4 & Viewing other contributors' sites \\
\hline
\end{tabular}

$\begin{array}{ll}3.5 & \text { Viewing and editing your profile }\end{array}$

$\begin{array}{lr}\text { References } & 17\end{array}$

Appendix 1. Allometric equations to estimate the aboveground biomass of trees used in this database 


\section{Introduction}

The Global Comparative Study on REDD+, established by CIFOR, supports a Forest Carbon Database and exchange system in the public domain. The database helps develop national and subnational monitoring, reporting and verification of REDD+ activities. The database is designed for an open access to allow participation of researchers and practitioners, who carry out regular forest inventory, manage permanent sample plots, and conduct research on forest carbon stocks and related topics.

This system allows you to account for five carbon pools: aboveground tree biomass, belowground tree biomass, dead woody debris, understorey/litter and soil. You can also add supporting information (details on your site, land cover, climate and soil) to build a profile of your carbon stock data. If you upload your entire inventory of data, the carbon stock in that ecosystem will be automatically calculated.

Our system offers the following advantages.

1. We help reduce duplicate data collection by making available data that have already been collected. This reduces costs.

2. We provide easy access to data that cannot be readily replicated, such as large surveys that are too expensive to replicate.

3. We help you compare carbon stocks across land use types based on data provided by other contributors.

This user guide is designed to familiarise the users with the features of the forest carbon database before deciding to participate and contribute to the system. 


\section{Getting started}

To access the Forest Carbon Database, go to http://carbonstock.cifor.cgiar.org/ on the Internet. From this home page, anyone can view a table setting out the total carbon stocks in different sites, as provided by contributors. For a more detailed look or to share your own data, you can register as a contributor. This section guides you through the registration process and logging on to the database.

\subsection{Registration}

1. Select Want to register? on the right side of the home page.

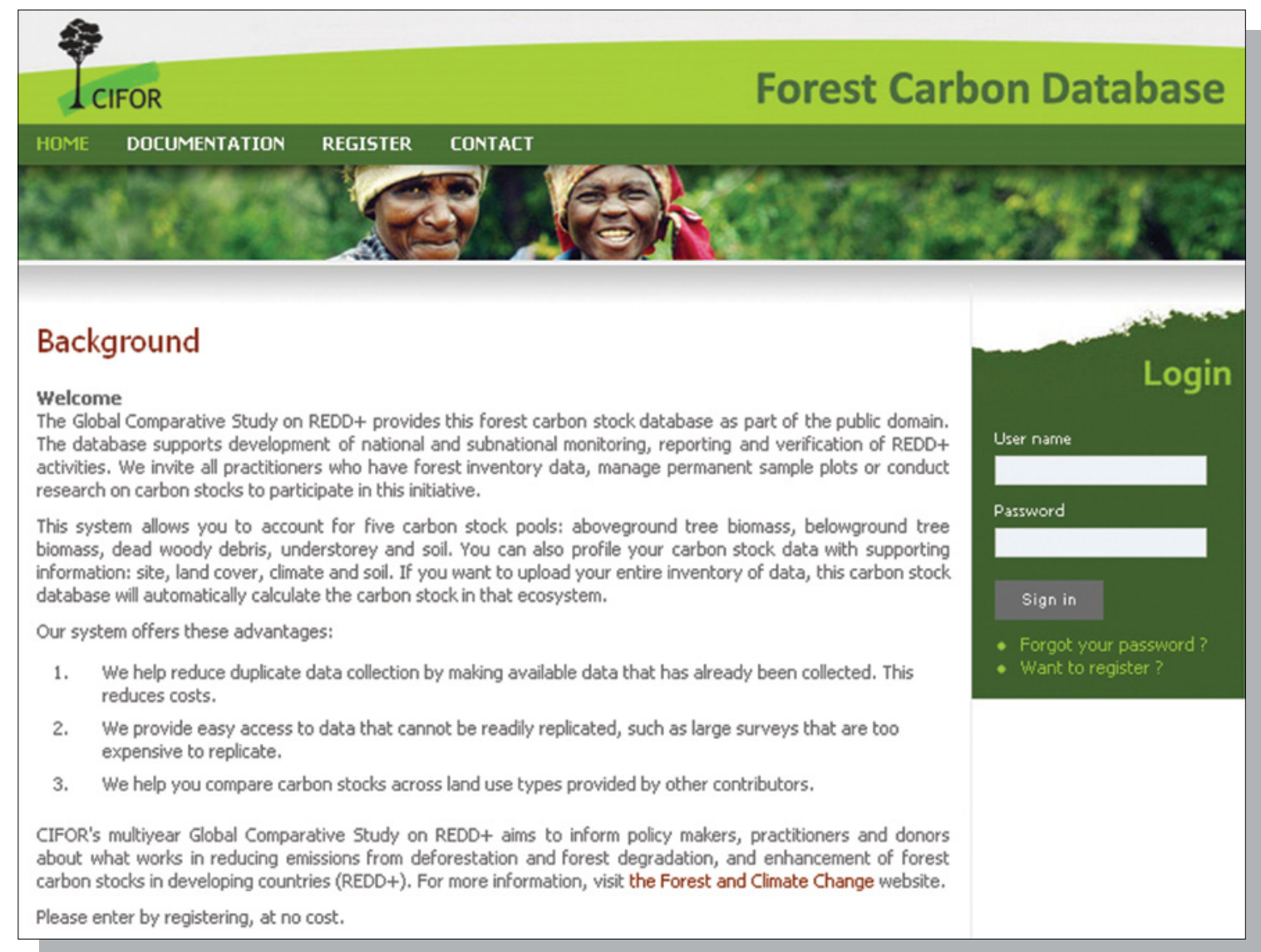




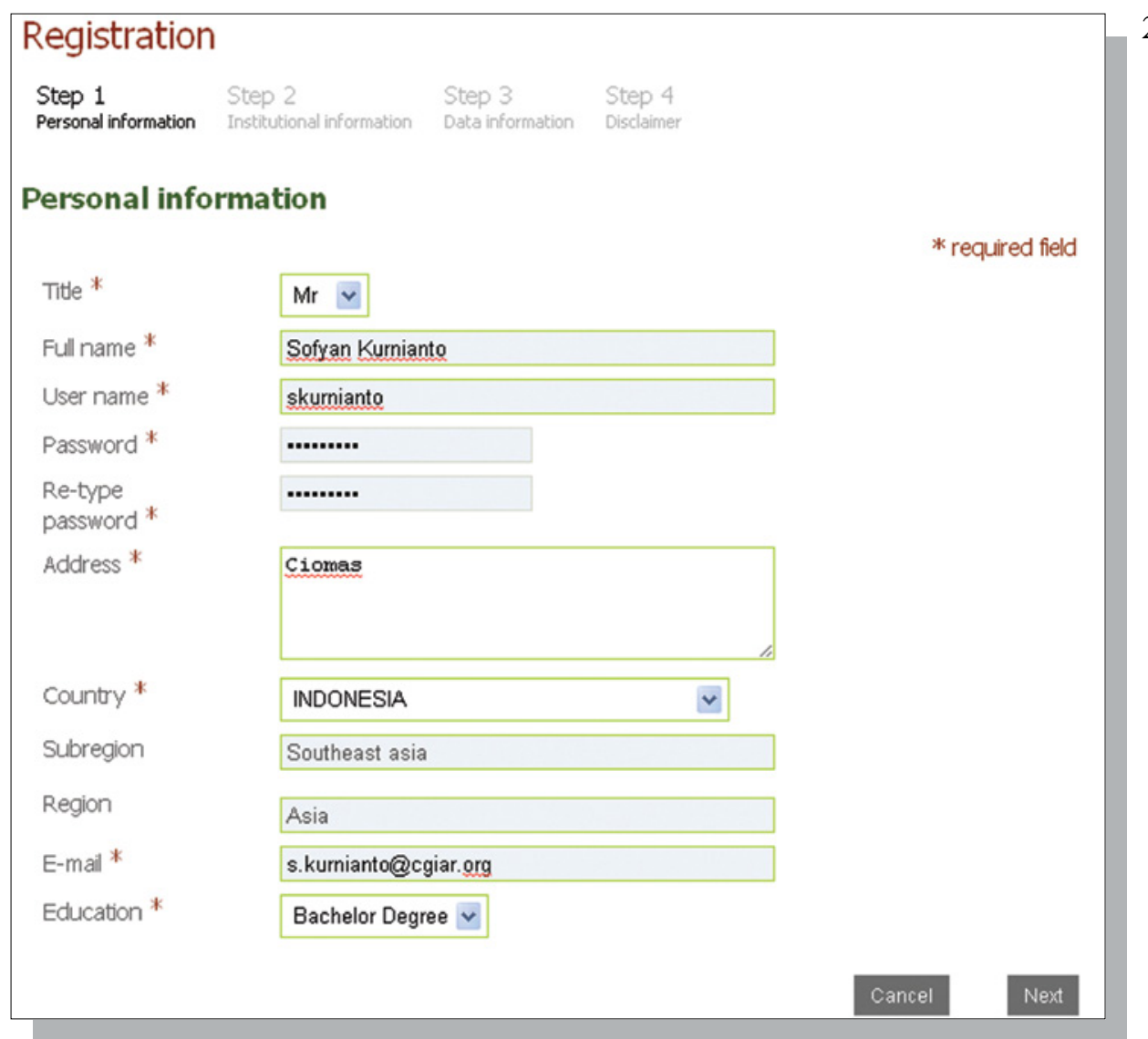

2. First, enter your personal information: name, address, email and education level. You can create your own user name and password. Click Next to move to the next step. Clicking Cancel at any point will terminate your registration.

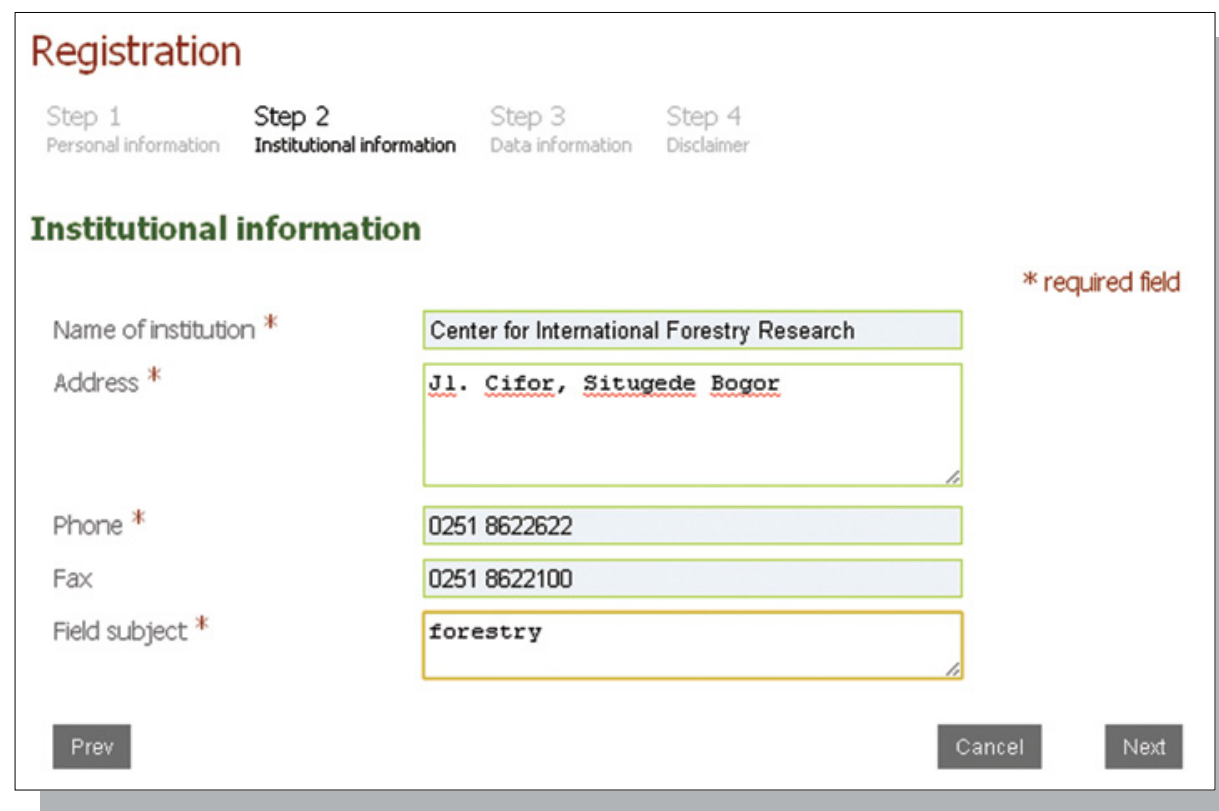

3. Enter information about the institution with which you are affiliated.

You must include a brief description of your institution's main area in Field subject; this might be, for example, forestry department, university or research station. 


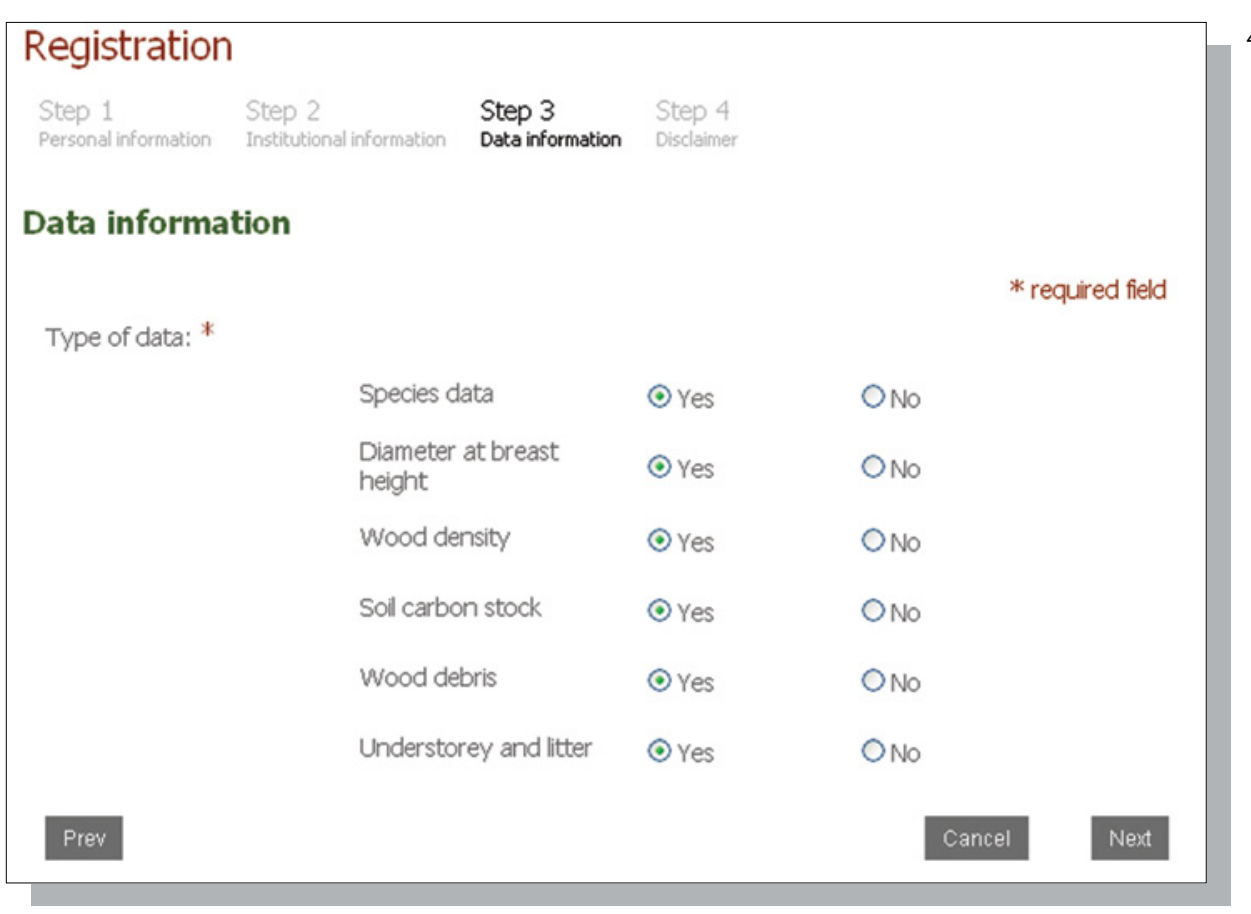

4. On the Data information page, enter details about the type of data in your research data set. For instance, if you have forest inventory data containing species data and diameter at breast height, you should select Yes for the Species data and Diameter at breast height fields.

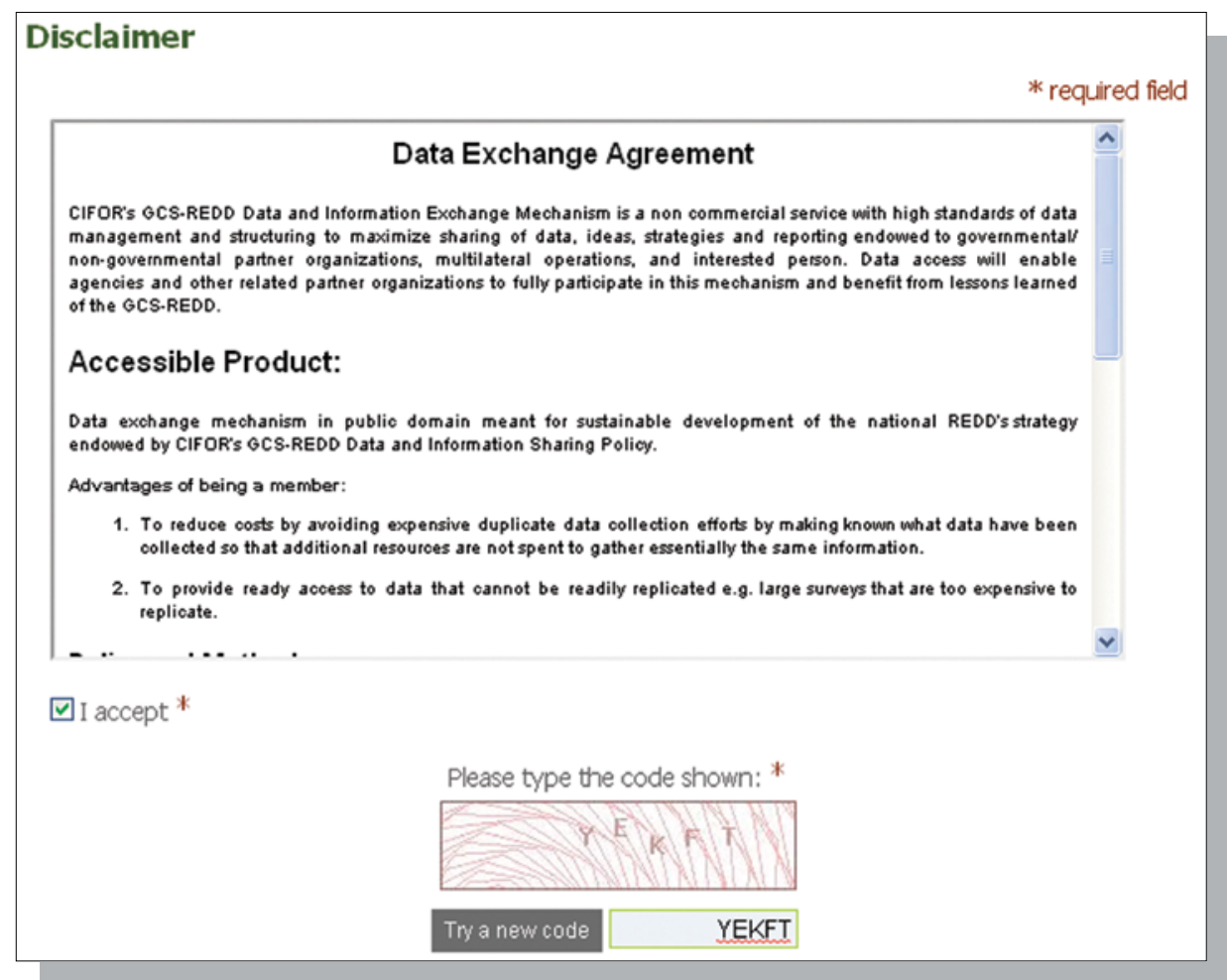

5. The data exchange agreement is given on the Disclaimer page. Please read it carefully. If you agree, tick 'I accept'. Type in the code shown, and then click Send registration to complete your registration.

When your registration is complete, the following page will appear. We will also send a notification to your email address for verification. 


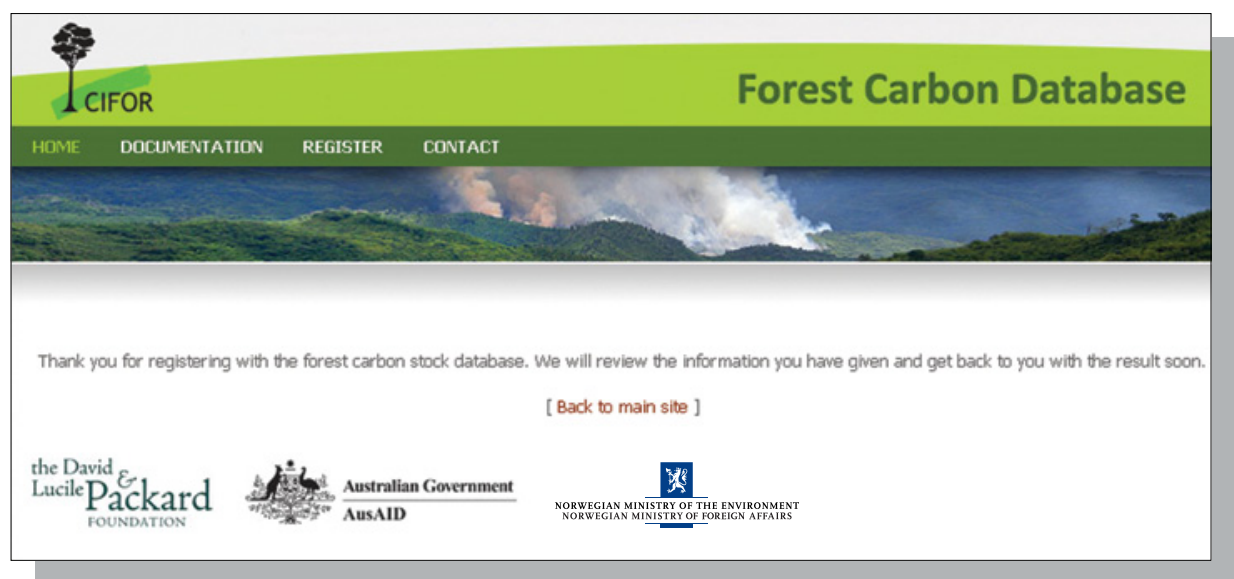

\subsection{Logging on to the forest carbon database}

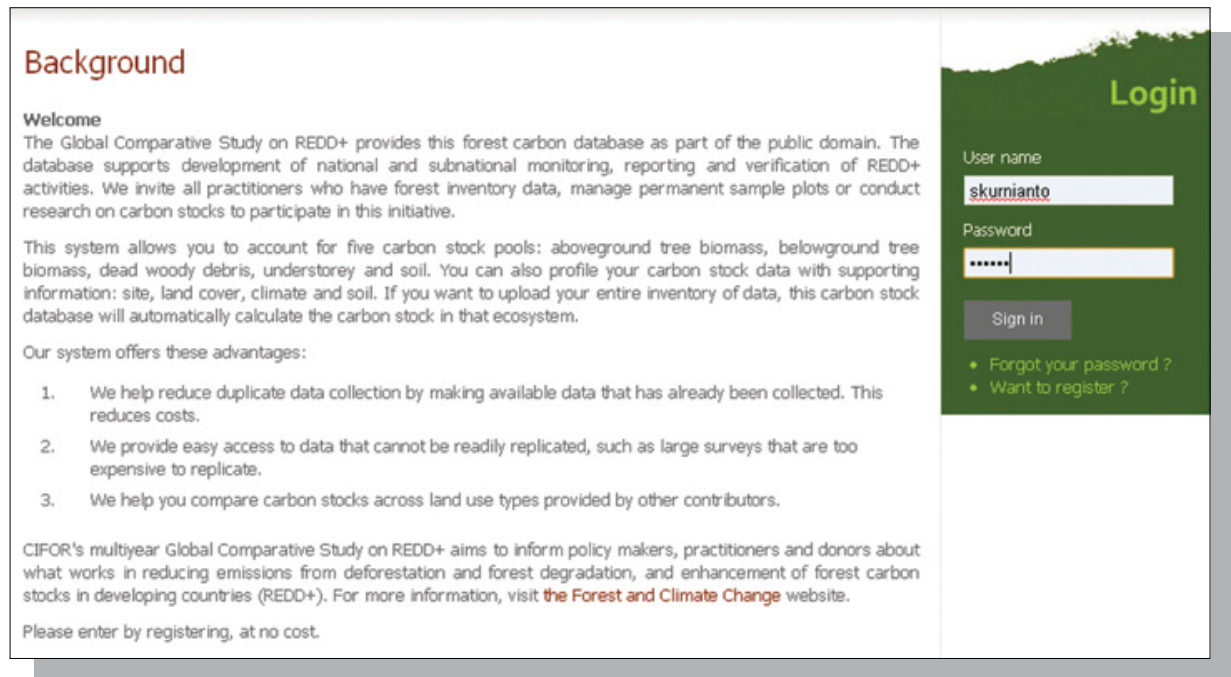

1. To log on, start from the forest carbon database home page at http://carbonstock. cifor.cgiar.org/. Enter your user name and password in the boxes on the right of the page and click Sign in. respond to the email, you can $\log$ on to the carbon stock database as a contributor.
6. Once you receive and

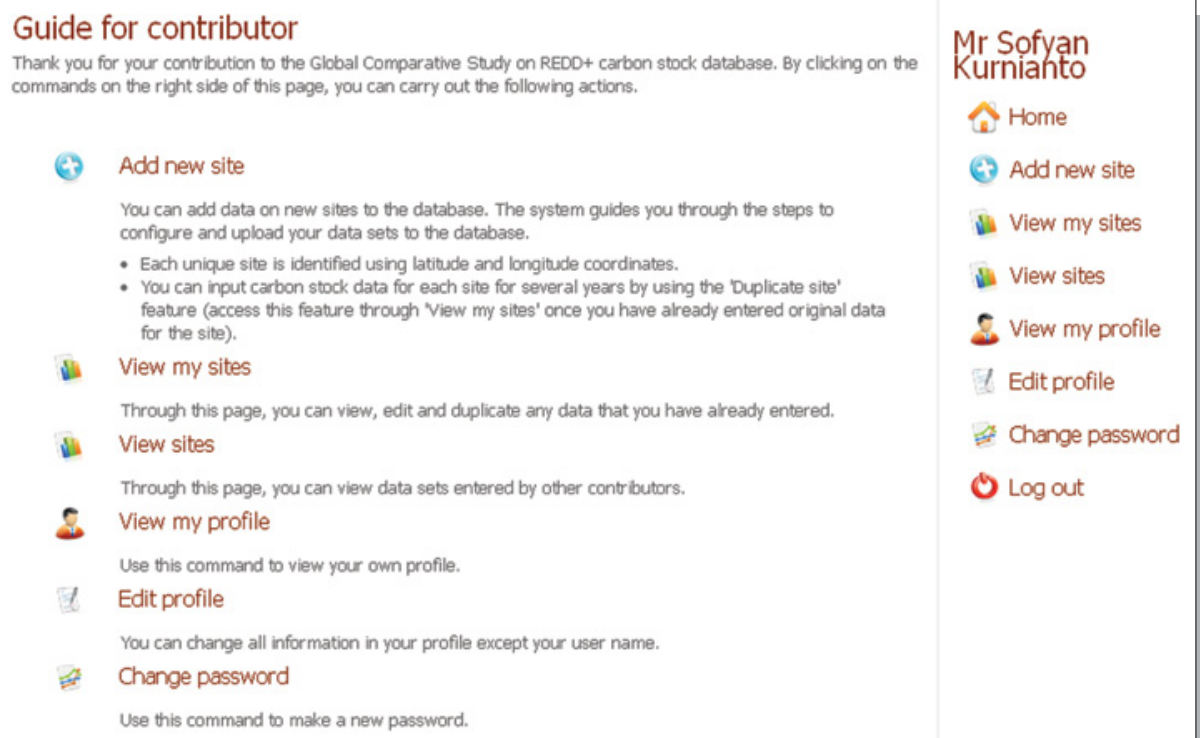

(4) Home
Add new site
I. View my sites
\& View my profile
Edit profile
Change password
L Log out

2. Your contributor home page will appear. From this page, you will be able to:
a. add new carbon stock data to the database;
b. view data provided by other contributors;
c. view other contributors' profiles; and
d. edit your profile and change your password.




\section{Recognising the features of the forest carbon database}

\subsection{Add new site}

Through this section, you can add new carbon stock data for a specific site. In this database, a 'site' represents a landscape with similar land cover type. The following guides you through the process of adding new carbon stock data.

1. Ensure you have already signed in to the forest carbon database system.

2. Click Add new site on the right side of the contributor landing page. The input form will appear; it comprises five tabs: Site description, Land cover, Climate, Soil and Total carbon stock. After you complete a tab, click Next to move to the next tab. Clicking Cancel at any time will terminate the process and you will be returned to your contributor home page.

3. Mandatory site details are location/administrative information, latitude, longitude, altitude and year of the field survey.

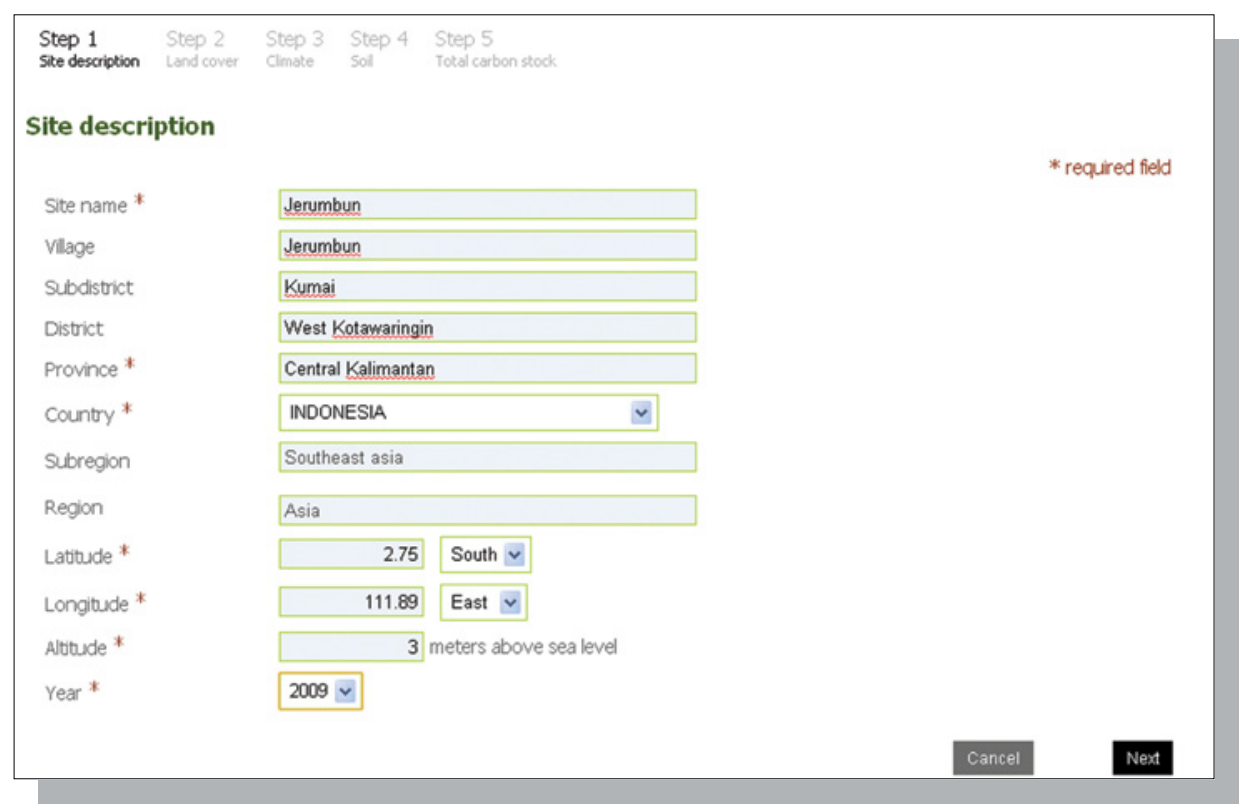

4. Choose the main land cover type in your site: natural forest or plantation. Then, select a more specific type from the dropdown list. You can select only one type of forests. Following are definitions of the options for natural forest land cover types.

a. Dry forest: A forest area in which annual precipitation is less than $1500 \mathrm{~mm}$ per year or which experiences more than five months of dry season.

b. Moist forest: A forest area in which evapotranspiration exceeds rainfall for more than one month but for less than five months. This forest is characterised by a semi-deciduous canopy, and annual precipitation for lowland forests usually ranges between 1500 and $3500 \mathrm{~mm}$.

c. Mangrove moist forest: A forest area in a coastal zone or tidal area. 
d. Wet forest: A forest area in which evapotranspiration exceeds rainfall for less than one month, and annual precipitation is greater than $3500 \mathrm{~mm}$.

e. Primary forest: A forest area comprising native tree species, in which indications of human activity are not clearly visible and ecological processes are not significantly disturbed.

f. Secondary forest: A forest area regenerating largely through natural processes after significant human disturbance of the original forest vegetation at a single point in time or over an extended period, and displaying a major difference in forest structure and/or canopy species composition with respect to nearby primary forests on similar sites.

g. Lowland mixed dipterocarp: Forest area dominated by the trees in the family Dipterocarpaceae.

In the Notes field, you can enter the characteristics of the forest in your site, such as the dominant species, logging activities, presence of a peat swamp, etc.
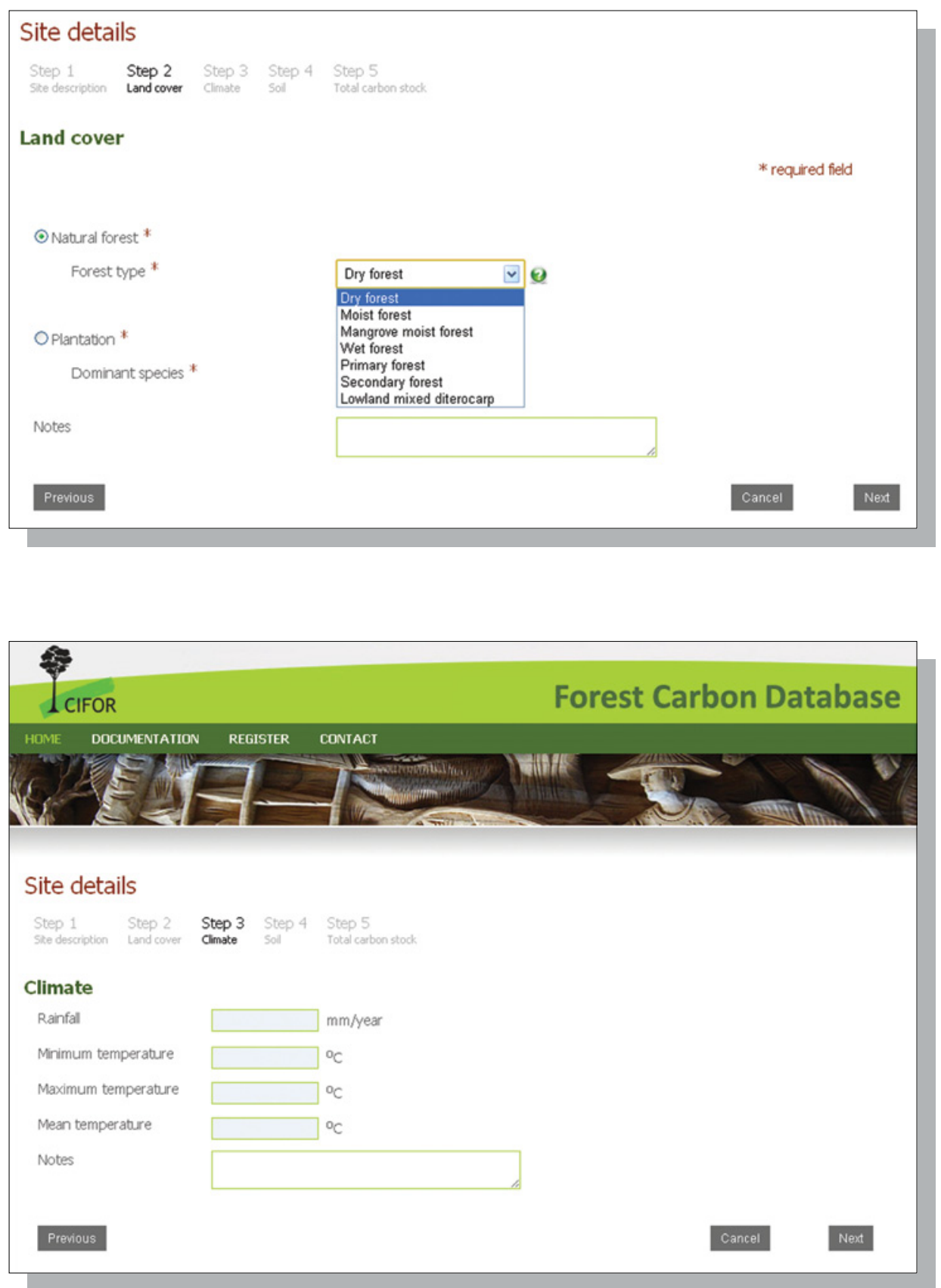

5. Next, provide details about the Climate in your site, that is, rainfall and temperature; if desired, you can add notes. 


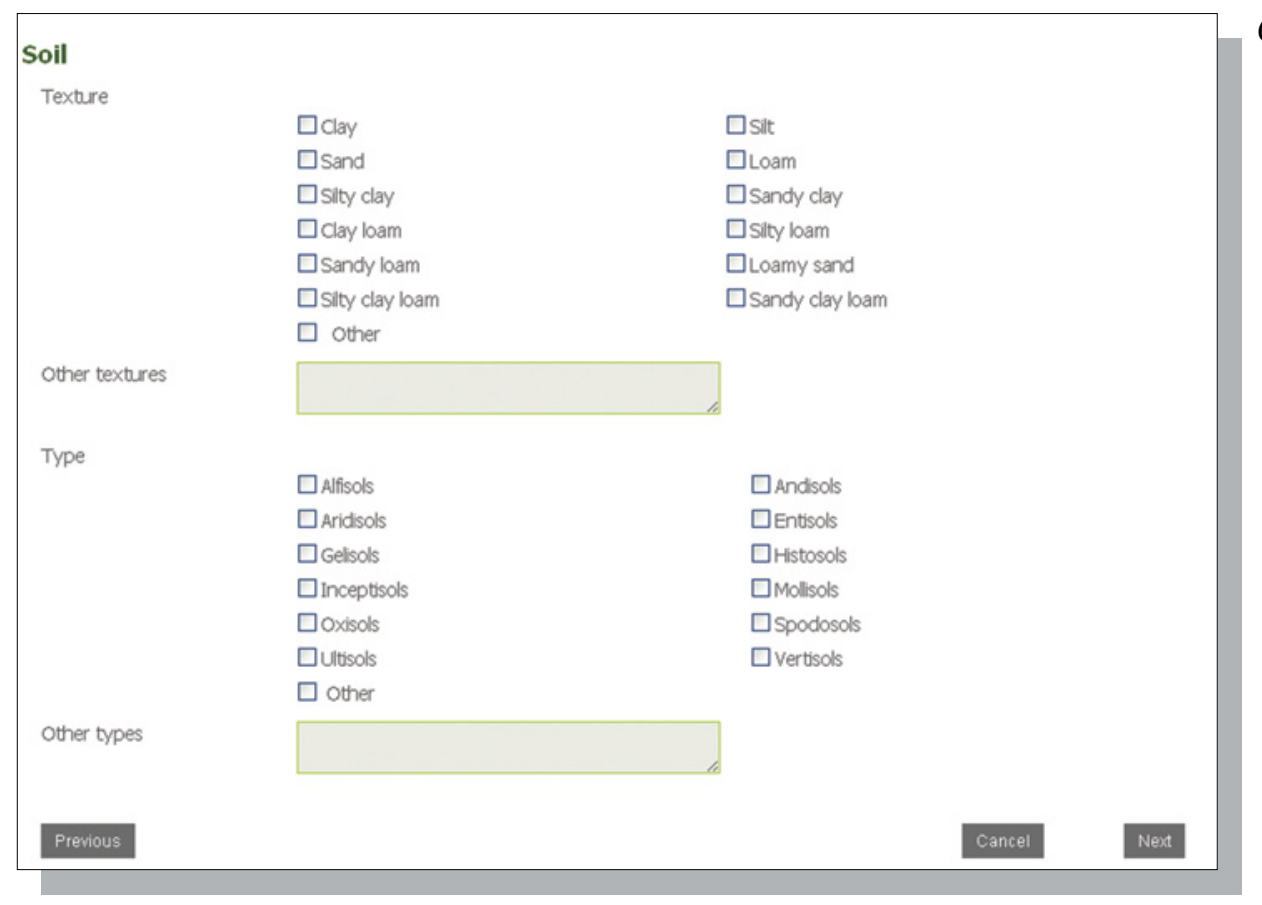

6. In the Soil tab, provide information about the soil texture and soil type. You can choose soil type and texture more than one option. If the relevant type or texture is not provided, select 'Other' and type in the information in the box provided.

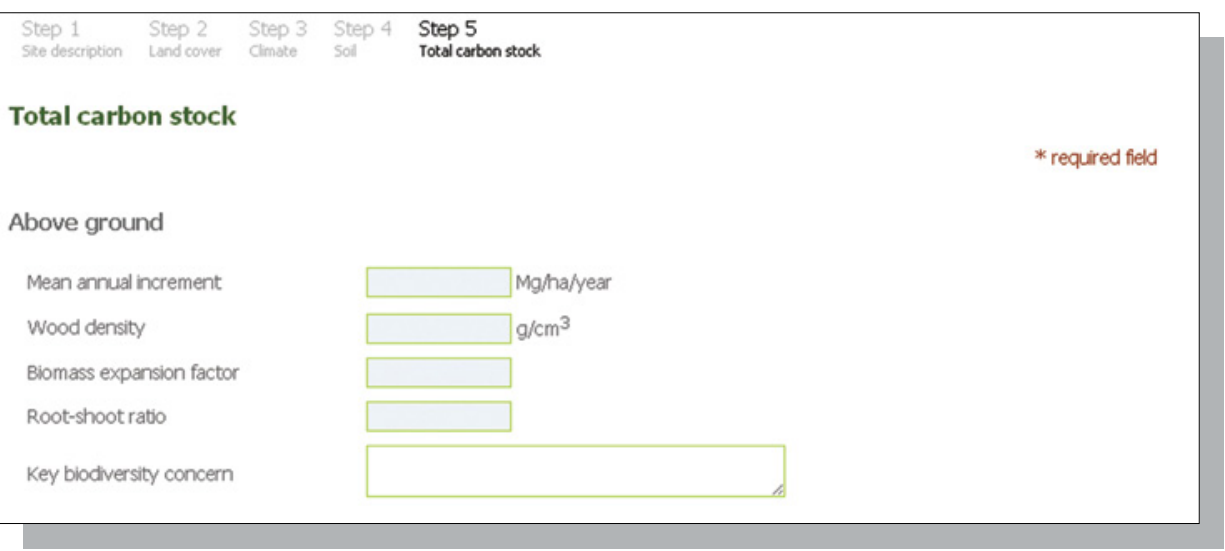

7. In the Total carbon stock tab, enter the values of mean annual increment, wood density, biomass expansion factor and root-shoot ratio in the appropriate boxes. Describe the general biodiversity condition in your site in the Key biodiversity concern box.

8. Next, enter the aboveground biomass of the trees and its carbon concentration in the appropriate box. The default value of carbon concentration is $50 \%$; however, you may change this value if preferred. The carbon stock value will be updated automatically after you input both biomass and carbon concentration.

9. In the woody debris section, you can enter values for fine and coarse woody debris biomass separately and the system will automatically calculate the total woody debris biomass. If your data do not distinguish fine and coarse woody debris, you can enter the woody debris value in the Total box.

10. Enter details about the understorey/litter and root biomass and their carbon concentration in the appropriate box. 


\begin{tabular}{|c|c|c|c|}
\hline \multicolumn{4}{|l|}{ Living biomass pools 9} \\
\hline \multicolumn{4}{|c|}{ Import and calculate biomass value 0 Upload Excel file } \\
\hline Trees* & $\begin{array}{l}\text { Biomass } \\
(\mathrm{Mg} / \mathrm{ha})\end{array}$ & $\begin{array}{l}\text { Carbon fraction } \\
(\%)\end{array}$ & $\begin{array}{l}\text { Carbon stock } \\
(\mathrm{Mg} \mathrm{C} / \mathrm{ha})\end{array}$ \\
\hline Total & 502.49 & 50 & 251.245 \\
\hline \multicolumn{4}{|l|}{ Dead biomass pools } \\
\hline \multicolumn{4}{|c|}{ Import and calculate total woody debris value 90 Uploas Excel file } \\
\hline Woody debris (3) & $\begin{array}{l}\text { Biomass } \\
(\mathrm{Mg} / \mathrm{ha})\end{array}$ & $\begin{array}{l}\text { Carbon fraction } \\
(\%)\end{array}$ & $\begin{array}{l}\text { Carbon stock } \\
\text { (Mg C/ha) }\end{array}$ \\
\hline Fine woody debris & & 50 & \\
\hline Coarse woody debris & & 50 & \\
\hline Total & 25.39 & 50 & 12.695 \\
\hline \multicolumn{4}{|c|}{ Upload raw data for understorey and litter Upload Excel file } \\
\hline $\begin{array}{l}\text { Understorey and litter } \\
\text { (3) }\end{array}$ & $\begin{array}{l}\text { Biomass } \\
(\mathrm{Mg} / \mathrm{ha})\end{array}$ & $\begin{array}{l}\text { Carbon fraction } \\
\qquad \%)\end{array}$ & $\begin{array}{l}\text { Carbon stock } \\
\text { (Mg C/ha) }\end{array}$ \\
\hline Total & 21.23 & 50 & 10.615 \\
\hline \multicolumn{4}{|l|}{ Below ground } \\
\hline Roots* & $\begin{array}{l}\text { Btomass } \\
(\mathrm{Mg} / \mathrm{ha})\end{array}$ & $\begin{array}{l}\text { Carbon fraction } \\
(\%)\end{array}$ & $\begin{array}{l}\text { Carbon stock } \\
\text { (Mg C/ha) }\end{array}$ \\
\hline Total & 99.19 & 50 & 49.595 \\
\hline
\end{tabular}

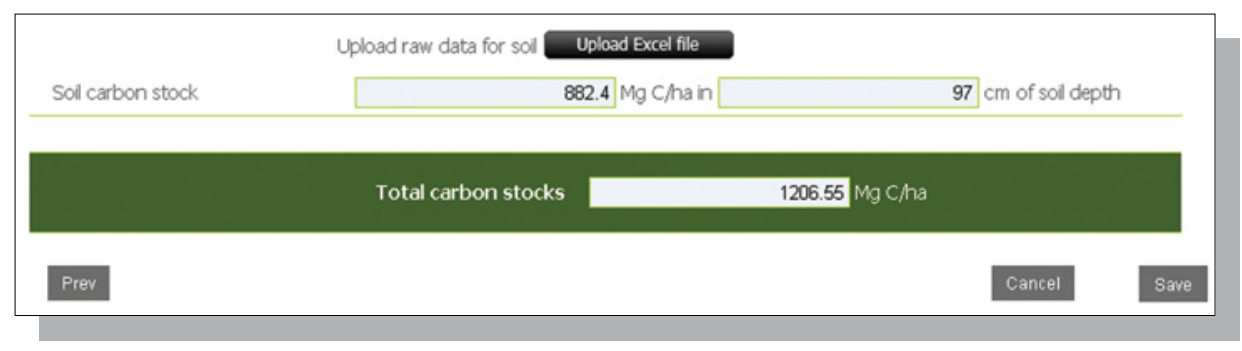

11. Enter the value of soil organic carbon at the specified soil depth in the appropriate box.

12. The system will calculate the total carbon stock in your site by summing the data you have entered.

\section{Box 1. Terms used in the Total carbon stock tab}

Biomass eixpansion factor: ratio of oven-dry aboveground biomass to oven-dry inventoried volume biomass.

Litter: all non-living biomass with a diameter less than the minimum diameter chosen by the site country (e.g. $10 \mathrm{~cm})$, lying dead and in various states of decomposition above the mineral or organic soil. This includes the litter, fumic and humic layers. Live fine roots (of less than the standard diameter limit for belowground biomass) are included in litter where they cannot be distinguished from it empirically.

Mean annual increment: the average annual growth that a tree or stand of trees has exhibited for a given period.

Root-shoot ratio: ratio of belowground biomass to aboveground biomass for a specific vegetation type.

Soil organic carbon: includes organic carbon in mineral and organic soils (including peat) to a specified depth chosen by the site country and applied consistently throughout the time series. Live fine roots (of less than the standard diameter limit for belowground biomass) are included with soil organic matter where they cannot be distinguished from it empirically.

Trees: all living biomass including stems, branches, twigs, bark and foliage of trees at breast height $(1.37 \mathrm{~m})$ or taller.

Understorey: all living biomass including stems, branches, twigs, bark and foliage for trees shorter than breast height (1.37 m).

Wood density: the dry mass of wood per unit volume.

Woody debris: all non-living woody biomass not included in litter, whether standing, lying on the ground or in the soil. Dead wood includes wood lying on the surface of the soil, dead roots and stumps at least $10 \mathrm{~cm}$ in diameter (or the appropriate diameter used as the standard in the site country). 


\subsection{Uploading raw data}

This section guides you through the process of adding new data to the database by uploading raw tree, wood debris, understorey/litter and soil survey data. The system then calculates the carbon stock for each pool based on the uploaded raw data.

The direct method proposed by IPCC (2003) is used to calculate the above and belowground carbon of trees in this system. This method requires the measurement of the diameter at breast height $(1.37 \mathrm{~m})$ of all the trees above the minimum diameter in the surveyed plots, as well as other data such as tree height and wood density. An allometric equation is employed to calculate the aboveground biomass of trees. The equation uses single or combined variables such as diameter, tree height and wood density as independent variables and aboveground biomass of trees as a dependent variable. Belowground biomass is calculated by using the equation of Cairns et al. (1997), which includes the relationship between aboveground biomass as an independent variable and belowground biomass as a dependent variable. A list of the allometric equations used in this system is given in Appendix 1. The following is a flowchart of the calculations of the aboveground carbon of trees.

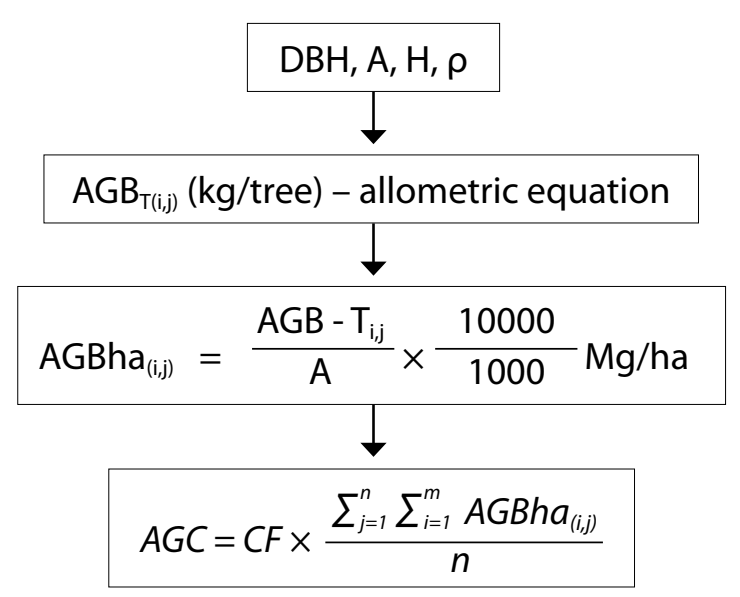

where:

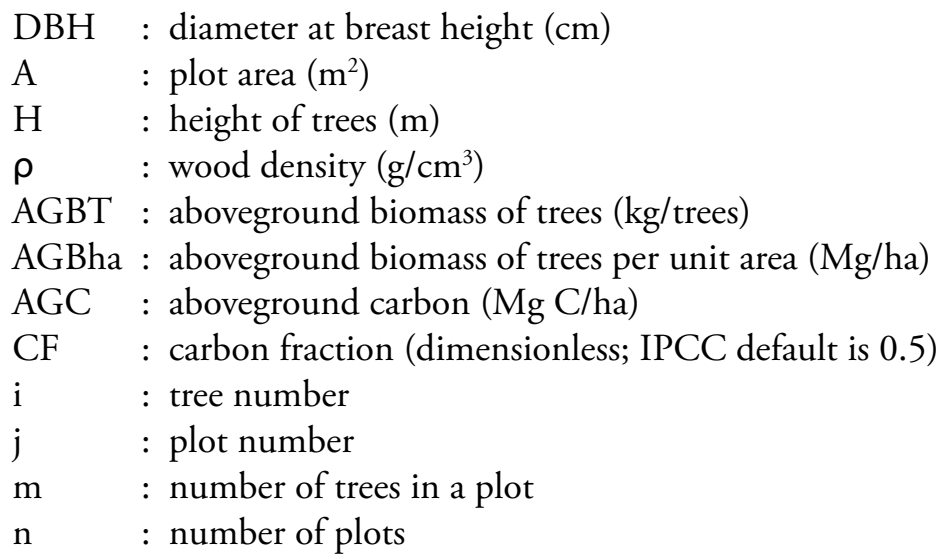


In this system, woody debris biomass is estimated using the line-intersect survey method. This is a time-efficient method that can be used when the debris quantity is expected to be a relatively small proportion of the total aboveground biomass (IPCC 2003). The diameters of all pieces of wood that intersect the line are measured, and debris is organised into density classes: rotten (fully decomposed) and sound (partially decomposed). The volume per hectare is estimated for each density class as follows (Brown 1974, IPCC 2003):

$$
V_{W D}=\frac{\left(\pi^{2} \sum D^{2}\right)}{8 L}
$$

where:

VWD : volume of woody debris per unit area $\left(\mathrm{m}^{3} / \mathrm{ha}\right)$

$\mathrm{D} \quad$ : diameter of each piece that intersects the line $(\mathrm{cm})$

$\mathrm{L} \quad$ : the length of the line (m)

Finally, the biomass of woody debris is calculated as follows:

$$
A G B_{W D}=\rho V_{W D}
$$

where:

$\mathrm{AGB}_{\mathrm{WD}}$ : aboveground biomass of woody debris $(\mathrm{Mg} / \mathrm{ha})$

$\rho \quad: \quad$ wood density of downed woody debris $\left(\mathrm{g} / \mathrm{cm}^{3}\right)$

For more information about estimating the biomass of woody debris, see Brown (1974), and Harmon and Sexton (1996).

Understorey and litter can be estimated using a simple harvesting technique (IPCC 2003). This technique uses a small frame (circular or square), usually encompassing an area of $0.5 \mathrm{~m}^{2}$, to collect all material inside the frame, including herbaceous plants, grasses, shrub and litter. A well-mixed subsample is collected to determine oven dry-towet weight ratios to convert the total wet mass to oven-dry mass.

The soil organic carbon stock is estimated by taking a soil sample in a sample plot. It is recommended that soil samples be taken at several depths. To estimate the soil organic carbon stock, the soil bulk density must be measured at each depth. The concentration of soil organic carbon at a given sample is usually estimated using either dry combustion or the Walkley-Black method. The soil organic carbon stock is estimated as follows:

$$
\mathrm{SOC}=[\mathrm{SOC}] \times \mathrm{BD} \times \text { Depth } \times 10
$$

where:

SOC : soil organic carbon $(\mathrm{Mg} / \mathrm{ha})$

[SOC] : the concentration of soil organic carbon in a given soil mass ( $\mathrm{g} \mathrm{C} / \mathrm{kg}$ soil sample)

BD : bulk density, the soil mass per sample volume $\left(\mathrm{Mg} / \mathrm{m}^{3}\right)$

Depth : the depth of the soil sample (m) 
The following steps guide you through the process of uploading raw data files.

1. Use Microsoft Excel 2003 to make four files, one each for trees, woody debris, understorey/litter and soil inventory data. Note, the system does not accept Excel 2007 (.xlsx) files at this time. Be sure to save your file as ('Save As') a .xls file (Excel 97-2003 Workbook). An Excel template is available for download from http:// carbonstock.cifor.cgiar.org/excel_template/. Box 2 shows the information required for each file.

\section{Box 2. Information for uploading raw data}

Aboveground living tree inventory

\begin{tabular}{|c|c|c|c|c|c|}
\hline Plot no. & Plot area $\left(\mathrm{m}^{2}\right)$ & Species & DBH $(\mathrm{cm})$ & Height $(\mathrm{m})$ & $\begin{array}{c}\text { Wood density } \\
\left(\mathrm{g} / \mathrm{cm}^{3}\right)\end{array}$ \\
\hline & & & & & \\
\hline & & & & & \\
\hline & & & & & \\
\hline & & & & & \\
\hline
\end{tabular}

Woody debris inventory

\begin{tabular}{|l|c|l|c|}
\hline \multirow{2}{*}{ Plot no. } & \multirow{2}{*}{$\begin{array}{c}\text { Transect } \\
\text { length }(\mathbf{m})\end{array}$} & \multicolumn{2}{|c|}{ Diameters of pieces $(\mathbf{c m})$} \\
\cline { 3 - 4 } & & Species & Rotten \\
\hline & & & \\
\hline & & & \\
\hline
\end{tabular}

Understorey/litter inventory

\begin{tabular}{|c|l|l|l|}
\hline \multirow{2}{*}{ Plot no. } & \multirow{2}{*}{ Plot area $\left(\mathrm{m}^{2}\right)$} & \multicolumn{2}{|c|}{ Dry litter mass $(\mathbf{g})$} \\
\cline { 3 - 4 } & & & \\
\hline & & & \\
\hline & & & \\
\hline
\end{tabular}

Soil samples

\begin{tabular}{|c|c|c|c|c|}
\hline Plot no. & $\begin{array}{c}\text { Sample depth } \\
\text { range }(\mathrm{cm})\end{array}$ & $\begin{array}{c}\text { Depth of } \\
\text { sample }(\mathbf{c m})\end{array}$ & $\begin{array}{c}\text { Bulk density } \\
\left(\mathbf{g} / \mathrm{cm}^{3}\right)\end{array}$ & $\begin{array}{c}\text { Organic } \\
\text { matter (\%) }\end{array}$ \\
\hline & & & & \\
\hline & & & & \\
\hline & & & & \\
\hline & & & & \\
\hline
\end{tabular}

Note: All fields in the above four tables are mandatory except Height and Wood density; enter the values for these fields only if the data are available. 
2. Repeat steps 1-6 in Section 3.1 to input information about your site and its land cover type, climate and soil condition.

3. Click Upload Excel file for each carbon pool, and select the relevant file from your folders.

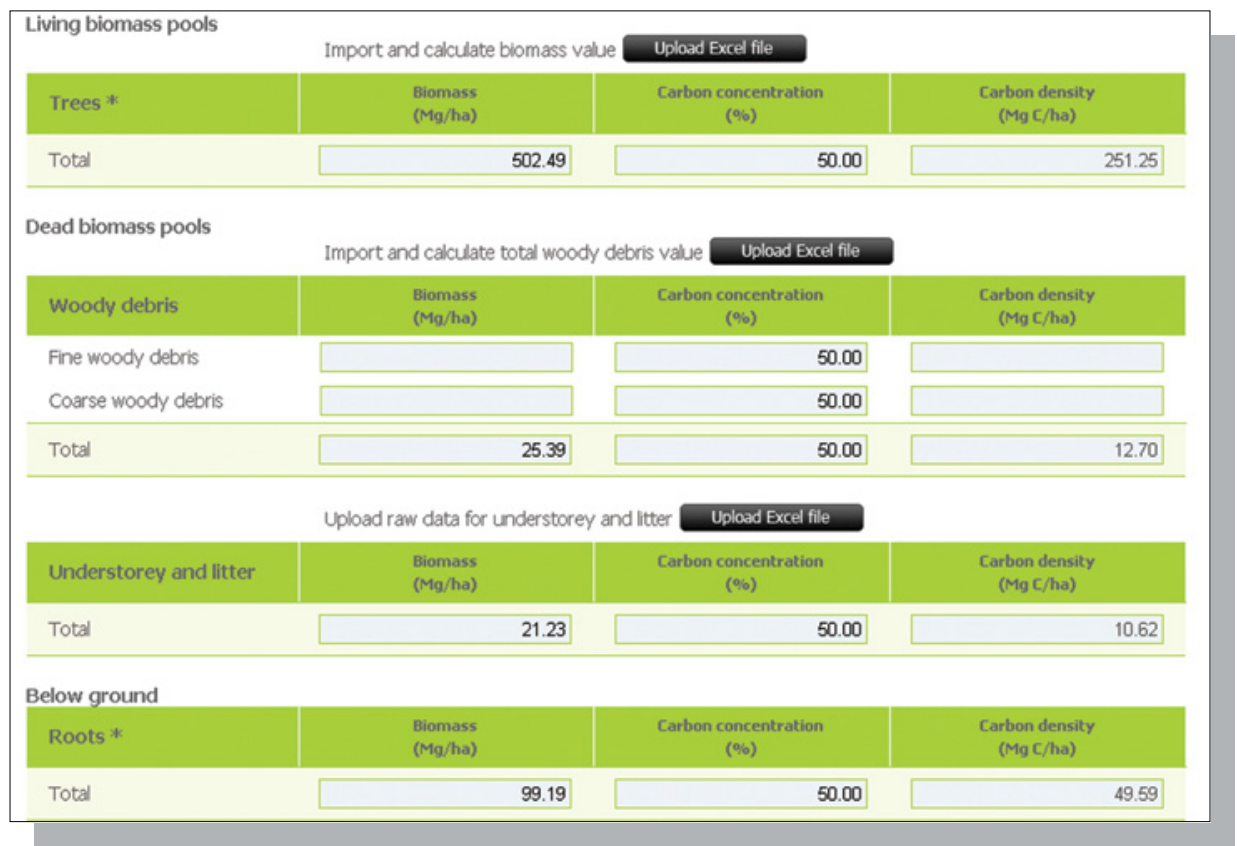

4. The system will upload the file to the database and calculate the carbon stock.

\subsection{Viewing, editing and duplicating your sites}

You can view any data you have saved in the database, starting from your contributor home page.

1. Click View my site on the right side of your contributor home page. This will take you to the List of my sites page. On this page, you can sort your data according to the carbon stock, year of measurement, site name, land cover type or country.

2. To view more details about a site, select it in the Site column.

3. To make changes to your data, click Edit. When you have finished editing your data, click Save on the Total carbon stock page to save your changes.

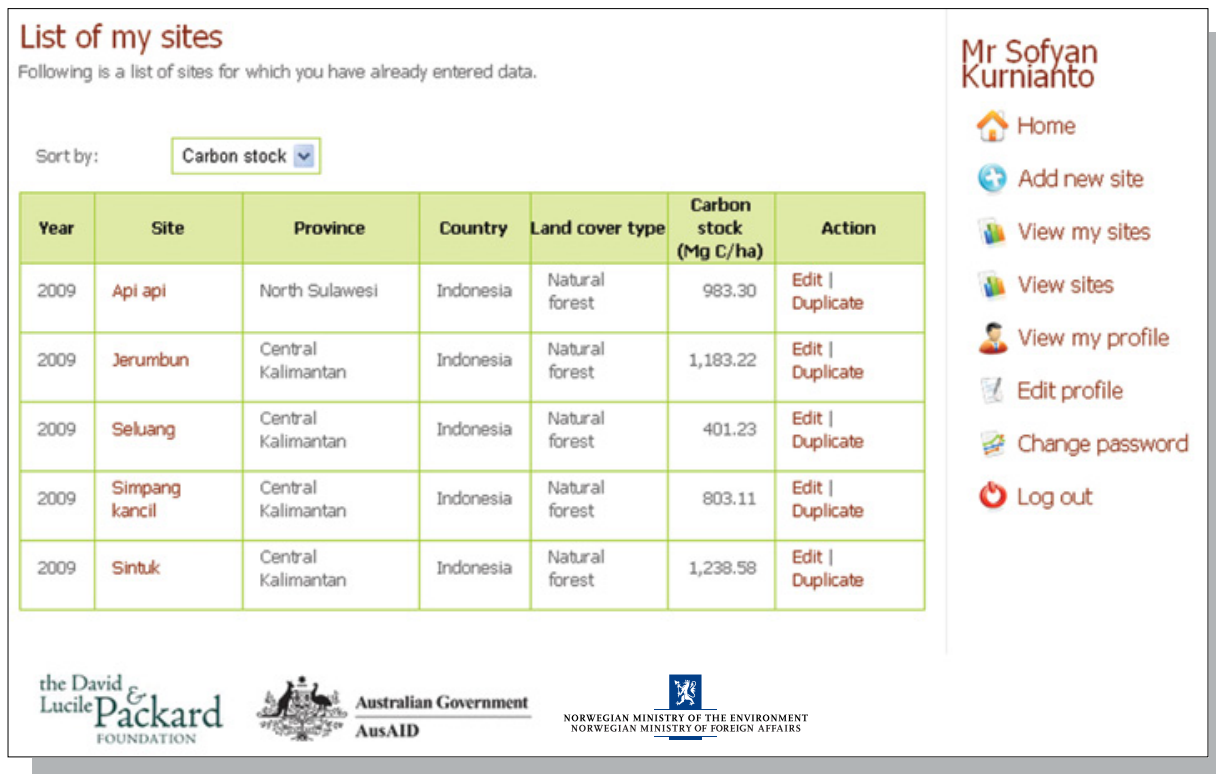

4. The 'Duplicate site' feature allows you to enter more than one set of carbon stock data for each site, so you can cover several years. To bring up the Site details duplicate page, click Duplicate against the desired site in the List of my sites page. 


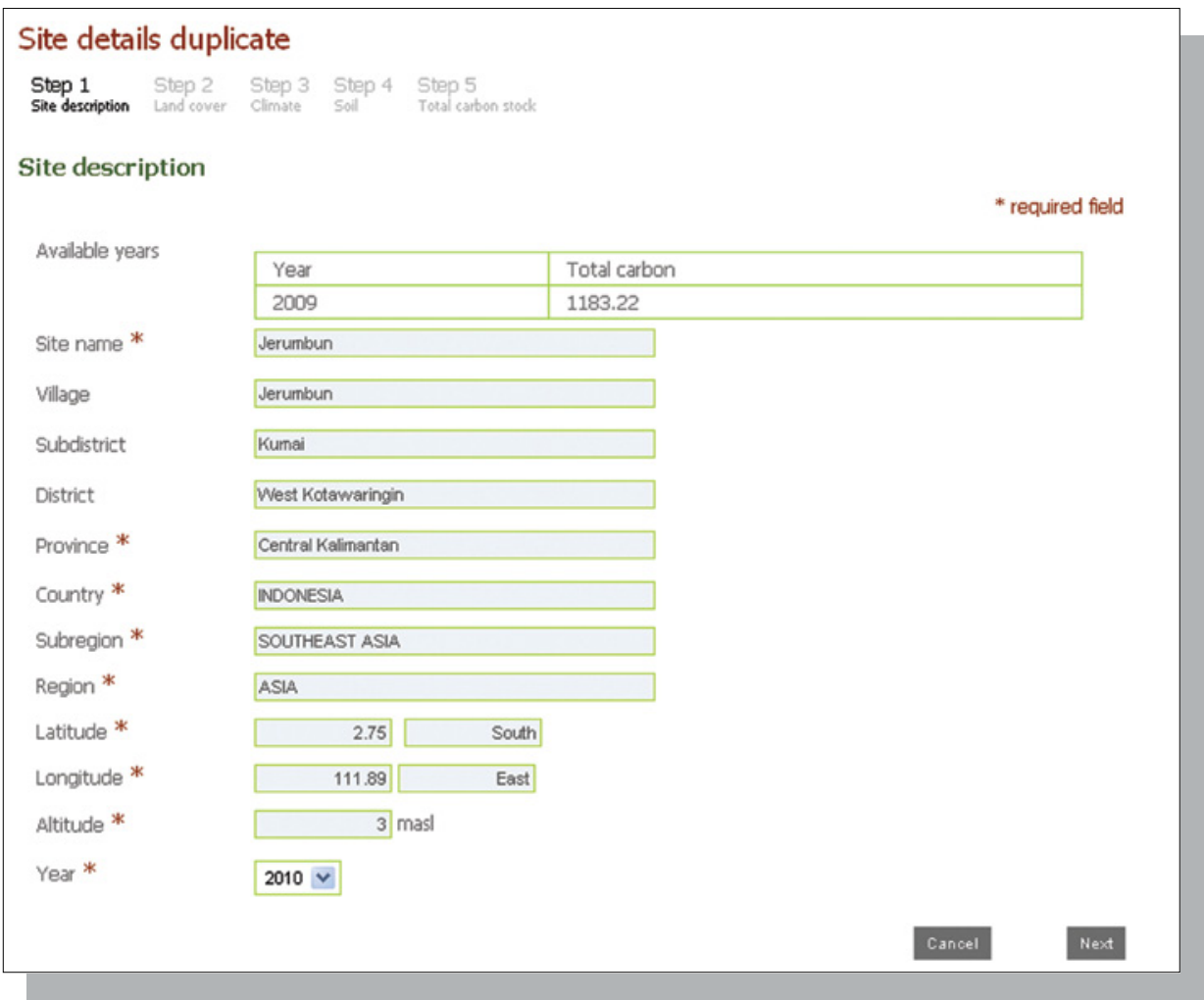

5. Select the Year based on the year of the field survey.

6. Add data on land cover type, climate, soil type and total carbon stock, according to the procedure detailed in Section 3.1.

\subsection{Viewing other contributors' sites}

1. Click View sites on the right side of your contributor home page. This will bring up the List of all sites page. You can sort the list according to the information that is most relevant to your needs.

2. Click on the name of a site that you want to view in detail.

\begin{tabular}{|c|c|c|c|c|c|c|c|}
\hline \multicolumn{7}{|c|}{$\begin{array}{l}\text { List of all sites } \\
\text { Following is a list of all sites that have been entered into the database. Select the Site or cont ibutor name for more } \\
\text { information. }\end{array}$} & \multirow{3}{*}{$\begin{array}{l}\text { Mr Sofyan } \\
\text { Kurniahto } \\
\text { A Home } \\
\text { Add new site } \\
\text { View my sites }\end{array}$} \\
\hline \multicolumn{2}{|c|}{ Sort by: } & \multicolumn{5}{|c|}{ Carbon stock $\vee$} & \\
\hline Year & Site & Province & Country & Land cover type & Contributor & $\begin{array}{c}\text { Carbon } \\
\text { stock } \\
\text { (Mg C/ha) }\end{array}$ & \\
\hline 2009 & Sintuk & $\begin{array}{l}\text { Central } \\
\text { Kalimantan }\end{array}$ & Indonesia & $\begin{array}{l}\text { Natural } \\
\text { forest }\end{array}$ & Sofyan Kurnianto & 1238.58 & View sites \\
\hline 2009 & Jerumbun & $\begin{array}{l}\text { Central } \\
\text { Kalimantan }\end{array}$ & Indonesia & $\begin{array}{l}\text { Natural } \\
\text { forest }\end{array}$ & Sofyan Kumianto & 1183.22 & E View my profile \\
\hline 2009 & Peramuan & $\begin{array}{l}\text { Central } \\
\text { Kalimantan }\end{array}$ & Indonesia & $\begin{array}{l}\text { Natural } \\
\text { forest }\end{array}$ & $\begin{array}{l}\text { Administrator of Forest } \\
\text { Carbon Database }\end{array}$ & 1061.00 & $\begin{array}{l}\text { Edit profile } \\
\text { Change password }\end{array}$ \\
\hline 2009 & Api api & $\begin{array}{l}\text { North } \\
\text { Sulawesi }\end{array}$ & Indonesia & $\begin{array}{l}\text { Natural } \\
\text { forest }\end{array}$ & Sofyan Kurnianto & 983.30 & O Log out \\
\hline 2009 & Risam & $\begin{array}{l}\text { Central } \\
\text { Kalimantan }\end{array}$ & Indonesia & $\begin{array}{l}\text { Natural } \\
\text { forest }\end{array}$ & $\begin{array}{l}\text { Administrator of Forest } \\
\text { Carbon Database }\end{array}$ & 977.53 & \\
\hline 2009 & $\begin{array}{l}\text { Simpang } \\
\text { kancil }\end{array}$ & $\begin{array}{l}\text { Central } \\
\text { Kalimantan }\end{array}$ & Indonesia & $\begin{array}{l}\text { Natural } \\
\text { forest }\end{array}$ & Sofyan Kurnianto & 803.11 & \\
\hline 2009 & Seluang & $\begin{array}{l}\text { Central } \\
\text { Kalimantan }\end{array}$ & Indonesia & $\begin{array}{l}\text { Natural } \\
\text { forest }\end{array}$ & Sofyan Kurnianto & 401.23 & \\
\hline $\begin{array}{l}\text { the Davi } \\
\text { Lucile P }\end{array}$ & Eckar & wisty & $\begin{array}{l}\text { ustralian } \mathrm{Ge} \\
\text { usAID }\end{array}$ & ment & 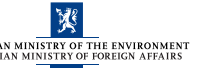 & & \\
\hline
\end{tabular}

3. To see more details about the person who submitted the data, click the name in the Contributor column. 


\subsection{Viewing and editing your profile}

1. To view or edit your profile, click View my profile or Edit profile on the right side of your contributor home page.

2. If you want to make a new password, click Change password. For this, you will be required to enter both your old and new passwords, and to confirm your new password.

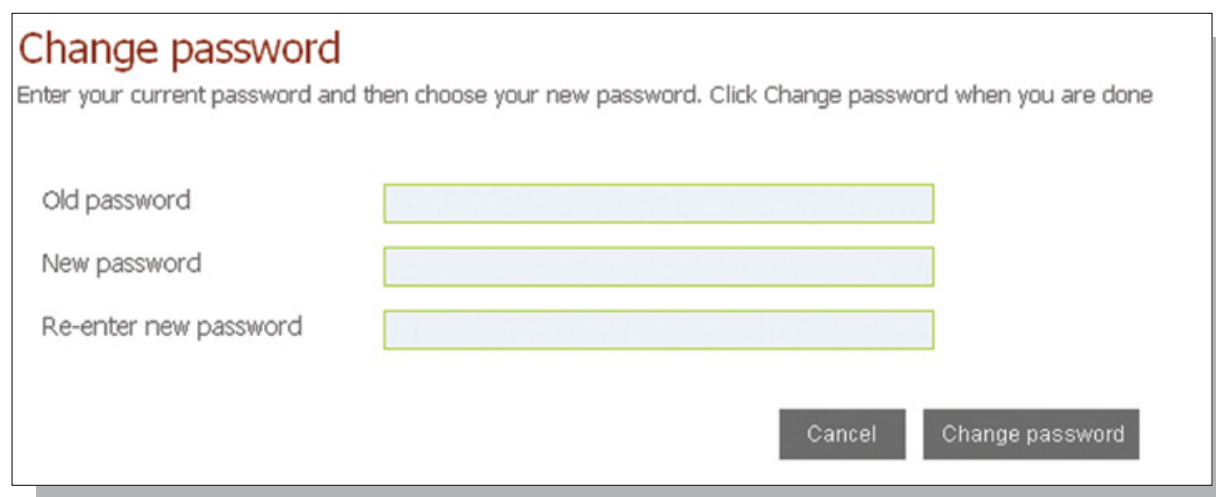

3. Click Change password to submit the change. 


\section{References}

Basuki, T.M., van Laake, P.E., Skidmore, A.K. and Hussin, Y.A. 2009 Allometric equation for estimating the above-ground biomass in tropical lowland Dipterocarp forests. Forest Ecology and Management 257: 1684-1694.

Brown, J.K. 1974 Handbook for inventorying downed woody material. USDA Forest Service General Technical Report INT-16. Ogden, Utah, USA.

Brown, S. 1997 Estimating biomass and biomass change of tropical forest: a primer. FAO Forestry paper 134, Food and Agriculture Organization of the UN, Rome.

Cairns, M.A., Brown, S., Helmer, E.H. and Baumgardner, G.H. 1997 Root biomass allocation in the world's upland forests. Oecologia 111: 1-11.

Chave, J., Andalo, C., Brown, S., Cairns, M.A., Chambers, J.Q., Eamus, D., Fölster, H., Fromard, F., Higuchi, N., Kira, T., Lescure, J.-P., Nelson, B.W., Ogawa, H., Puig, H., Riéra, B. and Yamakura, T. 2005 Tree allometry and improved estimation of carbon stocks and balance in tropical forests. Oecologia 145: 87-99.
Harmon, M.E. and Sexton, J. 1996 Guidelines for measurements of woody detritus in forest ecosystems. Publication no. 20. United States Long Term Ecological Research Network Office, University of Washington, Seattle, WA, USA.

Intergovernmental Panel on Climate Change (IPCC) 2003 Good practice guidance for land use, land-use change and forestry. Edited by Penman, J., Gytarsky, M., Hiraishi, T., Krug, T., Kruger, D., Pipatti, R., Buendia, L., Miwa, K., Ngara, T., Tanabe, K, and Wagner, F. IPCC National Greenhouse Gas Inventories Programme, Kanagawa, Japan.

Sierra, C.A., del Valle, J.I., Orrego, S.A., Moreno, F.H., Harmon, M.E., Zapata, M., Colorado, G.J., Herrera, M.A., Lara, W., Restrepo, D.E., Berrouet, L.M., Loaiza, L.M. and Benjumea, J.F. 2007 Total carbon stocks in a tropical forest landscape of the Porce region, Colombia. Forest Ecology and Management 243: 299-309. 


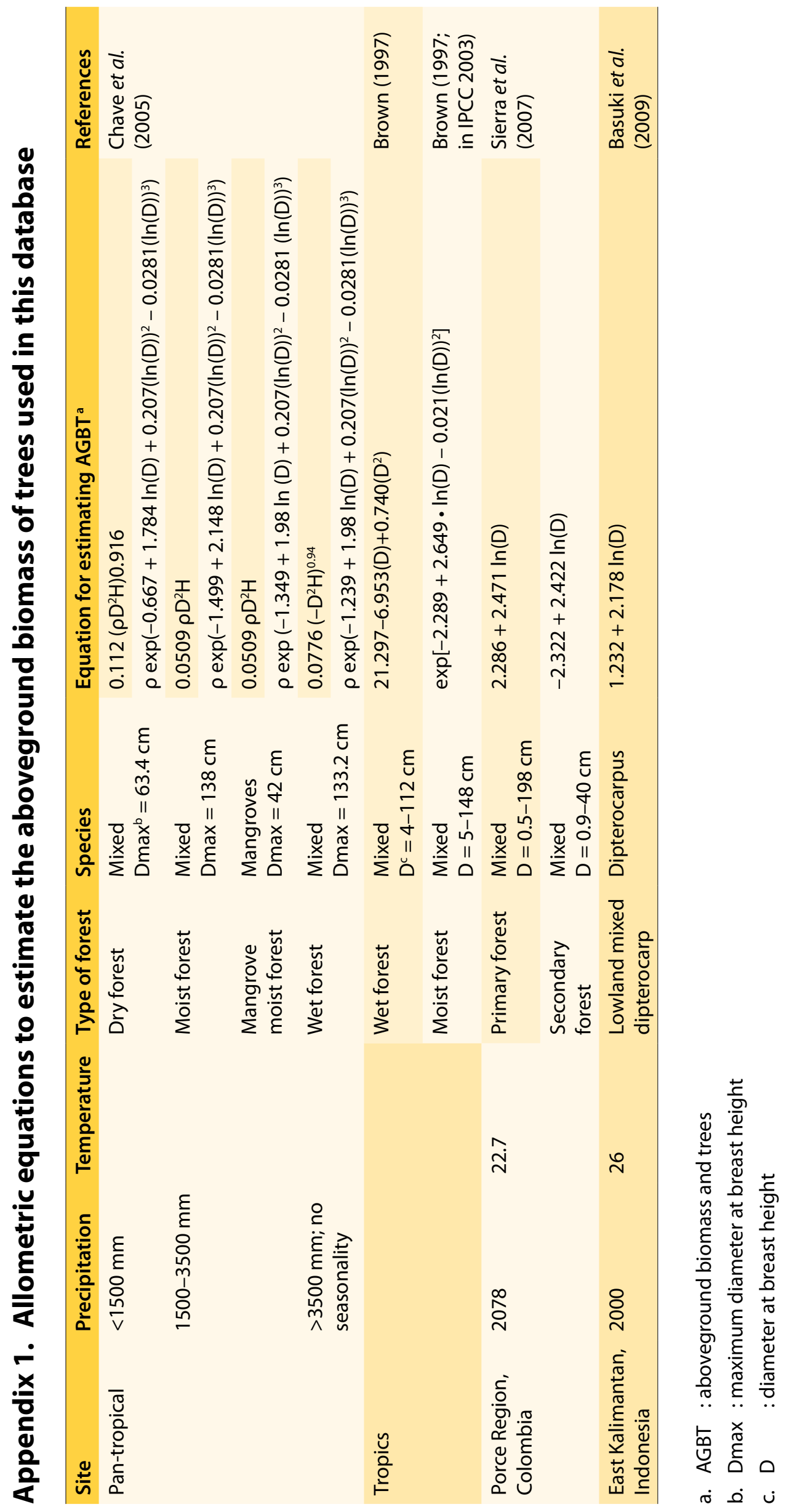



